\title{
Zjawiska chemiczno-technologiczne podczas zabiegu cementowania otworu w aspekcie projektowania rur okładzinowych
}

\section{Chemical-technological phenomena occurring during borehole cementing operations in terms of casing design}

\author{
Wiesław Witek ${ }^{1}$, Marcin Rzepka² \\ ${ }^{1}$ Firma Konsultingowa „WES” \\ ${ }^{2}$ Instytut Nafty i Gazu - Państwowy Instytut Badawczy
}

\begin{abstract}
STRESZCZENIE: Projektowanie otworów wiertniczych jest zagadnieniem kompleksowym i wielowymiarowym zarówno pod względem liczby kwestii, jakie stoją do rozwiązania przed projektantem, jak też pod względem wymogów w zakresie inżynierii mechanicznej, środowiskowej oraz bezpieczeństwa publicznego. W niniejszym artykule dokonano przeglądu i oceny zjawisk oraz procesów chemicznych (nie zawsze prawidłowo ocenianych), jakie zachodzą w trakcie sporządzania zaczynu cementowego oraz po jego wytłoczeniu w trakcie tworzenia się struktury żelowej cementu i kamienia cementowego. W wyniku skomplikowanego chemicznie przebiegu procesu wiązania zaczynu powstaje nowa struktura rura-kamień cementowy-skała, która w specyficzny sposób tworzy określony rodzaj obciążeń i naprężeń w przestrzeni pierścieniowej, wywierając wpływ na zmianę rozkładu ciśnienia hydrostatycznego. Tego rodzaju zjawiska opisane w niniejszym artykule pozwalają na zrozumienie metodycznego podejścia do procesu projektowania rur, w szczególności w aspekcie zgniatania i rozrywania rur o średnicy $>13 \% 3$ " i cienkiej ściance (w IV reżimie obciążeń). Nie znaczy to, że wytrzymałość rur na rozrywanie nie jest istotną kwestią w projektowaniu rur, ale dotyczy to głównie otworów bardzo głębokich, natomiast zgniatanie i rozrywanie rur występuje w szczególnych (często nieprzewidywanych) przypadkach pełnego lub częściowego opróżnienia dla małej głębokości posadowienia rur. Artykuł oparty jest na bogatej literaturze fachowej, jak również na licznych badaniach, jakie prowadzi się w laboratoriach Instytutu Nafty i Gazu - Państwowego Instytutu Badawczego w zakresie zaczynów cementowych i płuczek wiertniczych, a ponadto na stosownych doświadczeniach autorów artykułu - zarówno w zakresie projektowania zaczynów i nadzoru wykonania zabiegów cementowania, jak też projektowania i nadzoru prac związanych z realizacją wiercenia otworu, w tym zapuszczania i cementowania rur.
\end{abstract}

Słowa kluczowe: cementowanie rur okładzinowych, zaczyn cementowy, kamień cementowy, wiązanie zaczynu.

ABSTRACT: Borehole design is a complex and multidimensional question in terms of the number of issues to be resolved in terms of mechanical, environmental and public safety engineering requirements. In this article contains a review and evaluation of chemical phenomena and processes (not always correctly evaluated) that occur during the preparation of cement slurry and after its displacement during the formation of the gel structure of cement and cement sheath. As a result of the chemically complicated process of slurry gelation, a new structure is formed, i.e. steel pipe - sheath (cement stone) - a rock which in a specific way produces a specific type of load and stress in the annular space, and thus influences changes in hydrostatic pressure distribution. Such phenomena described in this article allow to understand the methodical approach to the process of designing pipes, especially in the aspect of collapse and burst of pipes with big diameter $>13 \% 8^{\prime \prime}$ and thin wall (in the $4^{\text {th }}$ load regime). This does not mean that the tensile strength of pipes is not an important issue in pipe design, but it mainly concerns very deep boreholes, while collapse and burst of pipes occurs in special (often unforeseen) cases of full or partial evacuation for shallow pipe foundation in the hole. The article is based on extensive professional literature, as well as on numerous tests carried out at Oil and Gas Institute - National Research Institute on different types of cement slurries and drilling muds, and, moreover, on the relevant experience of the authors of the article, both in the field of slurry design and supervision of cement operations, as well as in the design and supervision of works related to drilling of various types of boreholes, including cement job and running casing.

Key words: cementing of casing, cement slurry, cement sheath, cement setting.

Autor do korespondencji: M. Rzepka, e-mail: marcin.rzepka@inig.pl

Artykuł nadesłano do Redakcji: 21.10.2020 r. Zatwierdzono do druku: 26.01.2021 r. 


\section{Wprowadzenie}

Realizacja projektu wiercenia każdego otworu (nawet tego łatwego z punktu widzenia warunków geologiczno-technicznych) wymaga analizy licznych uwarunkowań geologicznych i technicznych, które muszą być uwzględnione w poszczególnych kategoriach projektowania, takich jak:

- technologia wiercenia, w tym zachowanie założonego parametru krzywizny otworu;

- technologia związana z zastosowaniem odpowiednio dobranej płuczki do warunków geologiczno-złożowych, w tym utrzymaniem i kontrolą równowagi ciśnień zarówno podczas wiercenia, jak też innych operacji, głównie cementowania poszczególnych kolumn rur okładzinowych;

- technologia cementowania dostosowana do stanu technicznego otworu oraz wartości ciśnień porowych, ciśnień szczelinowania i rozkładu temperatury w cementowanym profilu geologicznym;

- technologia doboru zaczynu cementowego w aspekcie uszczelnienia poszczególnych warstw geologicznych wokół kolumn rur okładzinowych oraz w aspekcie procesów zachodzących po związaniu zaczynu cementowego, w tym tworzenia się kamienia cementowego, $\mathrm{i}$ ich oddziaływania fizycznego na integralność struktury skała-kamień cementowy-rury okładzinowe.

Obok wyżej wymienionych podstawowych elementów technologicznych istotnych $\mathrm{w}$ realizacji projektu wiercenia nie mniej ważne jest właściwe zaprojektowanie poszczególnych kolumn rur okładzinowych. Proces tego projektowania wydaje się łatwy z punktu widzenia narzędzi stosowanych obecnie w praktyce wiertniczej, niemniej jednak w tym miejscu warto mocno podkreślić, że praktycznie nie jest możliwe idealne zaprojektowanie kolumny rur okładzinowych $\mathrm{z}$ uwagi na występowanie szeregu barier tak fizycznych jak i operacyjnych - stąd też w procesie projektowania rur okladzinowych przyjmuje się stosowne współczynniki projektowania zwane powszechnie ,współczynnikami bezpieczeństwa". Takie samo założenie można przyjąć w odniesieniu do procesu cementowania rur i uznać a priori, że nie da się idealnie zacementować danej kolumny rur tzn. wypelnić idealnie przestrzeni pierścieniowej ściana otworu-rury okładzinowe, a nawet przestrzeni pierścieniowej rura-rura.

Taki wniosek można wysnuć po analizie licznych przykładów stanu zacementowania rur okładzinowych.

W procesie projektowania otworu, a w szczególności projektowania rur okładzinowych i cementowania tych rur, zakłada się (często) teoretycznie idealne warunki stanu technicznego otworu, które dyktują niejako warunki brzegowe dla sporządzanego projektu. Takie założenia muszą zostać przyjęte na etapie wstępnego projektowania na podstawie ewentualnego rozpoznania geologicznego rejonu wiercenia lub innych danych, np. sejsmicznych. Niemniej jednak założenia te są często weryfikowane w trakcie wiercenia i dokonuje się bieżących zmian, w szczególności w odniesieniu do procesu cementowania, ale nigdy w odniesieniu do zaprojektowanych i zamówionych z wyprzedzeniem rur okładzinowych. Weryfikacja szczelności, a nawet wytrzymałości rur okładzinowych po procesie ich zapuszczenia i zacementowania wykonana na podstawie profilowania RBT lub LoT jest często świadectwem słuszności podjętych decyzji w procesie projektowania kolumny rur, ale niestety nie pozwala na dokonanie jakichkolwiek zmian z uwagi na niepodważalny fakt, że proces rurowania i cementowania jest najważniejszą i finalną czynnością w realizacji projektu wiercenia, ponieważ jest procesem nieodwracalnym.

Wszelkie błędy popełnione na etapie projektowania rur okładzinowych oraz na etapie projektowania zaczynu cementowego i operacji cementowania rur są często przyczyną kosztownych komplikacji wiertniczych, a w skrajnych przypadkach kończą się nawet utratą otworu.

W tym oraz kolejnym artykule autorzy będą się starać wykazać, w jaki sposób proces projektowania zaczynu cementowego, a także samo cementowanie i zjawiska chemiczno-technologiczne związane z tą technologią wpływają na kwestie projektowania poszczególnych kolumn rur okładzinowych oraz na kwestie ich wytrzymałości (szczególnie na zgniatanie) - zarówno w momencie wytłaczania zaczynu cementowego jako substancji płynnej, jak też po związaniu zaczynu cementowego i utworzeniu się kamienia cementowego, a więc po powstaniu „struktury samonośnej” niezależnej od struktury geologicznej skał otaczających ani od stalowej struktury rur okładzinowych. Istotną kwestią w tej relacji nowej struktury, czyli „stalowa rura okładzinowa-kamień cementowy-skała”, jest brak jakichkolwiek informacji co do rozkładu naprężeń w obrębie struktury kamienia cementowego przy jednoczesnym posiadaniu w miarę dobrej wiedzy dotyczącej naprężeń, jakie panują lub mogą panować w strukturze samej rury i strukturze otaczających skał lub w obrębie ściany otworu.

Tego rodzaju sytuacja dyktuje szereg warunków, jakie powinny być uwzględnione $\mathrm{w}$ procesie projektowania rur i zaczynów cementowych.

\section{Opis zjawiska chemicznej hydratacji cementu}

Hydratacja zaczynu cementowego jest bardzo złożonym procesem przebiegającym w mieszaninie cementu $\mathrm{z}$ wodą (Neville, 2000; Kurdowski, 2010, 2014; Ridi, 2010; Dębińska, 2013). W czasie wiązania i rozwoju wytrzymałości mechanicznej zachodzi seria reakcji hydratacji, które mają kluczowe 
znaczenie dla wytrzymałości powstającego kamienia cementowego. Hydratacja cementu nie ma charakteru liniowego w czasie. Początkowo proces przebiega powoli, co pozwala na odpowiednie umiejscowienie ziaren cementu przed związaniem.

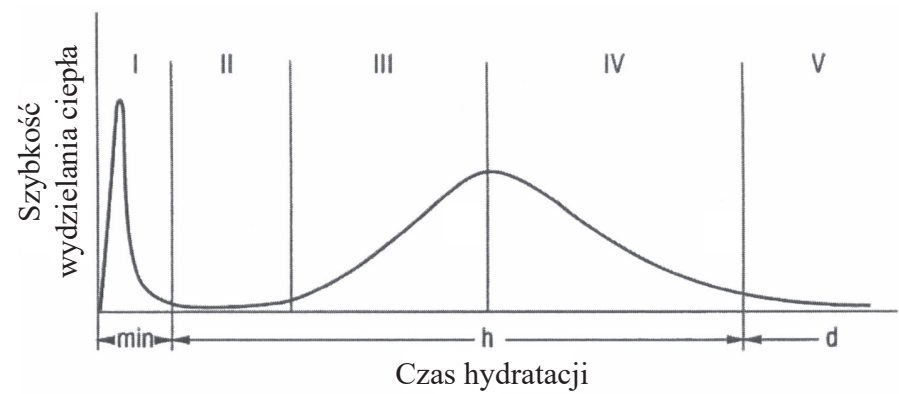

Rys. 1. Krzywa kalorymetryczna hydratacji fazy $\mathrm{C}_{3} \mathrm{~S}$

Fig. 1. Hydration curve for $\mathrm{C}_{3} \mathrm{~S}$

Hydratacja fazy $\mathrm{C}_{3} \mathrm{~S}$, z uwagi na jej większe natężenie w porównaniu do hydratacji fazy $\mathrm{C}_{2} \mathrm{~S}$, jest głównym źródłem początkowego wiązania i rozwoju wytrzymałości na ściskanie w stwardniałym zaczynie. $Z$ kolei hydratacja $\mathrm{C}_{2} \mathrm{~S}$ odpowiada za końcową wytrzymałość cementu. Obydwa mechanizmy przebiegają w bardzo podobny sposób. Bazując na krzywej kalorymetrycznej hydratacji fazy $\mathrm{C}_{3} \mathrm{~S}$ (rys. 1), można wyróżnić pięć etapów reakcji hydratacji cementu:

I. Etap przedindukcyjny - trwający do kilku minut, o największym stopniu wydzielania ciepła (najbardziej egzotermiczny). Następuje wówczas gwałtowne uwodnienie cementu natychmiast po kontakcie z wodą. Powstaje początkowa warstwa żelu C-S-H na powierzchni fazy $\mathrm{C}_{3} \mathrm{~S}$.

II. Etap indukcji - następuje spadek wydzielania ciepła i powolne wytrącanie żelu C-S-H, a także wzrost koncentracji jonów $\mathrm{Ca}^{2+}$ i $\mathrm{OH}^{-}$. Po osiągnięciu pełnego nasycenia w roztworze wytrąca się $\mathrm{Ca}(\mathrm{OH})_{2}$. Etap ten trwa około kilku godzin. W publikacjach Kurdowskiego (2010, 2014) wyróżniane są dwie teorie jego przebiegu tj.:

- teorię warstwy ochronnej - zgodnie $\mathrm{z}$ nią przepuszczalność powstałego żelu C-S-H jest niska, co powoduje zahamowanie dalszego procesu hydratacji i rozpoczęcie etapu indukcji. Według jednego z mechanizmów w warstwie C-S-H tworzą się siły osmotyczne, które po pewnym czasie doprowadzają do pęknięcia warstwy C-S-H i powstania znacznej ilości wtórnego żelu C-S-H. Następnie warstewka żelu C-S-H przechodzi morfologiczne przemiany powodujące wzrost przepuszczalności, przez co woda łatwiej przedostaje się do warstwy, przyspieszając dalszą hydratację;

- teorię opóźnionej krystalizacji - wytrącanie $\mathrm{Ca}(\mathrm{OH})_{2}$ przyspiesza proces hydratacji. W tej teorii mowa jest o szeregu odwrotnych mechanizmów związanych z okresem indukcji. Według jednego z mechanizmów przechodzące do roztworu jony $\mathrm{Ca}^{2+} \mathrm{i} \mathrm{OH}^{-}$powodują wzrost stopnia nasycenia wapnem, co prowadzi do opóźnienia hydratacji $\mathrm{C}_{3} \mathrm{~S}$ ze względu na wysoką koncentrację jonów $\mathrm{Ca}^{2+}$.

III. Etap wzrostu szybkości reakcji - to najbardziej gwałtowny etap hydratacji. $\mathrm{Ca}(\mathrm{OH})_{2}$ zaczyna krystalizować z roztworu i C-S-H odkłada się na przestrzeniach wypełnionych wodą. Hydraty rozrastają się, tworząc całość strukturalną przyszłego kamienia cementowego.

IV. Etap zmniejszenia szybkości reakcji - maleje porowatość układu, transport jonów i wody przez siatkę żelu C-S-H ulega spowolnieniu, a natężenie hydratacji spada.

V. Etap małej szybkości reakcji - proces hydratacji trwa dalej. Struktura ulega zagęszczeniu, zmniejsza się porowatość i następuje wzrost wytrzymałości na ściskanie. Ten etap może trwać bardzo długo.
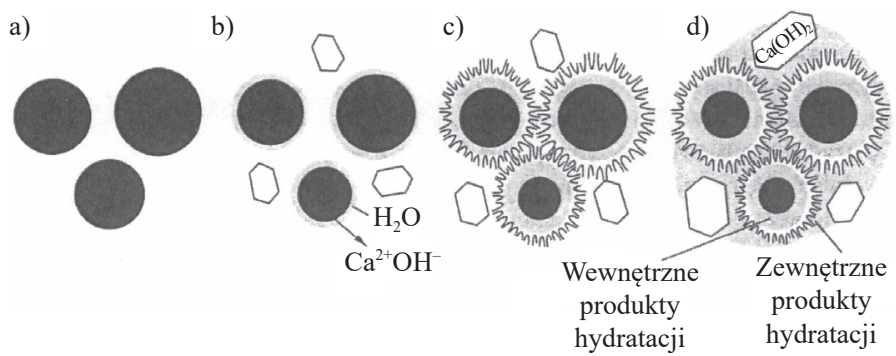

Rys. 2. Etapy hydratacji cementu: a) ziarna cementu rozproszone są w wodzie, b) utworzenie warstwy żelu C-S-H na ziarnach cementu, c) rozerwanie warstw żelu pod ciśnieniem osmotycznym i narastanie wtórnego żelu C-S-H, d) wypełnienie porów w zaczynie po dłuższym czasie (pełny wzrost fazy C-S-H i wodorotlenku wapnia)

Fig. 2. Stages of cement hydration: a) cement grains are dispersed in water, b) formation of a C-S-H gel layer on cement grains, c) the rupture of the gel layers under osmotic pressure and build up of secondary C-S-H gel, d) filling the pores in cement slurry after a longer time (full growth of C-S-H phase and calcium hydroxide)

Rysunek 2 obrazuje sekwencję etapów procesu hydratacji cementu. Proces ten polega na równoległych reakcjach bezwodnych składników z wodą. Krzemian trójwapniowy $\mathrm{C}_{3} \mathrm{~S}$ odpowiada za powstanie żelu C-S-H i wodorotlenku wapnia w początkowym etapie hydratacji, natomiast krzemian dwuwapniowy $\mathrm{C}_{2} \mathrm{~S}$ - w późniejszym etapie reakcji. W trakcie procesu hydratacji następują zmiany stężenia zawartych w fazie ciekłej jonów, które powodują zmiany szybkości procesu.

Hydratacja faz glinowych, głównie $\mathrm{C}_{3} \mathrm{~A}$, jest najbardziej aktywna we wczesnej fazie tego procesu. Fazy glinowe mają znaczący wpływ na reologię zaczynu cementowego, a także na wytrzymałość powstającego kamienia cementowego. Hydratacja $\mathrm{C}_{4} \mathrm{AF}$ przebiega podobnie jak w przypadku $\mathrm{C}_{3} \mathrm{~A}$, tylko wolniej. Pierwszym jej etapem jest reakcja międzyfazowa między cząsteczkami nieuwodnionymi a wodą. Hydraty glinianowe nie tworzą warstwy ochronnej na powierzchni 
w przeciwieństwie do hydratów krzemianowych, dlatego też nie występuje tu etap indukcji i proces hydratacji zachodzi bardzo gwałtownie (Rzepka et al., 2019).

\section{Charakterystyka poszczególnych parametrów zaczynu cementowego}

Projektowanie zaczynu cementowego w odniesieniu do zakładanego profilu geologicznego i związanych z tym profilem parametrów ciśnienia porowego, ciśnienia szczelinowania i rozkładu temperatury statycznej i dynamicznej stanowi element tworzenia bariery fizycznej mający wpływ na totalną niezawodność oddziaływania złożonego systemu powstającego po zapuszczeniu rur okładzinowych, a więc nowego systemu - struktury, jakim jest skała-zaczyn cementowy/kamień cementowy-rura okładzinowa. Ten nowy system musi zapewnić operacyjną integralność w ciągu wszystkich cykli fazowych, jakie mogą zachodzić w otworze. Głównym wymaganiem natury fizycznej systemu skała-zaczyn/kamień cementowy-rura okładzinowa jest zachowanie szczelności i wytrzymałości struktury dla różnych zakładanych scenariuszy operacyjnych, jakie są planowane w danych otworze, lub występowania skrajnie niekorzystnych warunków obciążeń struktury, na granicy jej zniszczenia lub trwałego uszkodzenia. Do takich scenariuszy można zaliczyć m.in.:

- utratę kontroli ciśnień podczas cementowania;

- wywołanie dopływu płynu złożowego do przestrzeni struktury;

- powstanie niepożądanej wolnej przestrzeni, tzw. microannulus, w trakcie testów ciśnieniowych;

- wywołanie zjawiska zgniatania rur okładzinowych w momencie utraty oddziaływania ciśnienia hydrostatycznego już w procesie żelowania zaczynu lub przekroczenie dopuszczalnych ciśnień zgniatania rur na skutek skrajnego opróżnienia tych rur w trakcie wiercenia lub w trakcie planowanego technologicznego opróżnienia kolumny.

Hydrostatycznym elementem bariery fizycznej jest kolumna płynu lub płynów wywierających ciśnienie hydrostatyczne, które z reguły musi przewyższać ciśnienie porowe płynu złożowego dla potencjalnej strefy dopływu. Do takich płynów można zaliczyć:

- płuczkę;

- bufor cementowy;

- zaczyn cementowy (w fazie płynnej);

- wodę lub płyn pakerowy.

Bardzo ważne jest, aby zrozumieć i brać pod uwagę fakt, że oddziaływanie hydrostatyczne wyżej wymienionych płynów może ulegać zmianie (na ogół powoduje obniżenie ciśnienia hydrostatycznego) na skutek procesu sedymentacji płuczki lub buforu, jak również procesu solidyfikacji zaczynu cementowego, czyli powstawania kamienia cementowego w procesie żelowania i tworzenia struktury statycznej wytrzymałości żelowej (SGS, ang. static gel strength). Praktycznie wytłoczony zaczyn cementowy w momencie rozpoczęcia procesu żelowania zaczyna natychmiast tracić właściwość transmisji ciśnienia hydrostatycznego (Sabins, 1982).

Zjawisko żelowania dotyczy również samych płuczek wiertniczych, aczkolwiek utrata oddziaływania hydrostatycznego jest nieporównywalnie mniejsza niż w przypadku żelowania zaczynu.

Proces tworzenia się struktury żelowej, opisany w innym rozdziale niniejszego artykułu, kończy się praktycznie po osiągnięciu wytrzymałości kamienia cementowego na poziomie 250 psi (czyli około 17 bar lub 1,7 MPa). W tym momencie należy zakładać, że zaczyn cementowy traci kompletnie swoje oddziaływanie hydrostatyczne, które zostaje przejęte przez działanie innych płynów, takich jak:

- woda zarobowa;

- płyn złożowy;

- płuczka zastosowana w procesie cementowania.

Zjawisko utraty ciśnienia hydrostatycznego w procesie wiązania zaczynu cementowego jest szeroko udokumentowane w literaturze i nie stanowi aktualnie żadnej kontrowersji, w szczególności dla założeń i warunków brzegowych przy projektowaniu rur okładzinowych (Nelson, 1990).

Rodzaj płynu, jaki powstaje lub pozostaje po procesie wiązania zaczynu cementowego w przestrzeni pomiędzy rurami okładzinowymi a kamieniem cementowym lub skałą, jest bardzo istotny w procesie projektowania i obliczeń wytrzymałościowych rur okładzinowych. Zawsze dla takich obliczeń należy przyjąć taki rodzaj płynu, jaki jest najbardziej niekorzystny dla uzyskania bezpiecznych wartości obciążeń przenoszonych na daną kolumnę rur okładzinowych. Problem ten został szerzej poruszony w rozdziale dotyczącym projektowania rur.

Zagadnienie projektowania i testowania laboratoryjnego zaczynu cementowego zostało szeroko opisane w bogatej literaturze przedmiotu (PN-EN ISO 10426-1:2010; PN-EN ISO 10426-2:2006). W niniejszym artykule nie omówiono całej sfery technicznej związanej z wierceniem otworu (technologia płuczkowa) i wykonaniem zabiegu cementowania, jak również nie opisano wyposażenia technologicznego - zarówno w zakresie sprzętu cementacyjnego, jak też uzbrojenia czy wyposażenia zapuszczanej kolumny rur okładzinowych. Zakłada się, że kwestie techniczne związane z procesem wiercenia, rurowania i cementowania nie stanowią problemu w zrozumieniu zjawisk, o których jest mowa w artykule.

Generalnie każdy zabieg cementowania ma na celu:

- zapewnienie odpowiedniej izolacji hydraulicznej w okresie pracy otworu; 
- skuteczne wypełnienie odpowiednim zaczynem cementowym przestrzeni pierścieniowej pomiędzy ścianą otworu a rurą lub poszczególnymi rurami;

- zapewnienie zabezpieczenia antykorozyjnego rur przez utworzony kamień cementowy;

- uzyskanie odpowiednich własności mechanicznych kamienia cementowego dla utrzymania trwałego podparcia mechanicznego (utwierdzenia);

- uszczelnienie kolumny rur okładzinowych w otworze, jak również uzyskanie minimalnej przyczepności kamienia cementowego do powierzchni zewnętrznej rur.

$\mathrm{W}$ procesie projektowania zaczynu cementowego rozważane i badane są różne parametry mające istotny wpływ na jakość zabiegu cementacyjnego, a w konsekwencji na integralność całego otworu w okresie jego eksploatacji, w szczególności integralność nowej struktury powstałej po związaniu zaczynu, czyli struktury skała-kamień cementowy-rura okładzinowa.

Do istotnych parametrów z punktu widzenia projektowania zaczynu i skuteczności procesu cementowania oraz zjawisk, jakie powstają po związaniu zaczynu i utworzeniu się kamienia cementowego, można zaliczyć takie parametry jak:

- właściwości reologiczne zaczynu;

- kontrola hydrostatycznego oddziaływania zaczynu i kamienia cementowego;

- kontrola wielkości filtracji zaczynu;

- kontrola wielkości tworzenia się wolnej wody i sedymentacji;

- kontrola procesu żelowania zaczynu cementowego w aspekcie parametru static gel strength (SGS);

- kontrola odporności na dopływ płynu złożowego (gaz, solanka itp.);

- kontrola i badania wytrzymałości kamienia cementowego - UCA;

- kurczenie się lub ekspansja zaczynu cementowego i ich skutki;

- trwałość kamienia cementowego w czasie;

- badanie odporności kamienia cementowego na korozję. Proces projektowania i badania właściwości zaczynu cementowego oraz kamienia jest oparty na licznych standardach API oraz PN i jest szeroko opisany w literaturze przedmiotu (PN-EN ISO 10426-1:2010; PN-EN ISO 10426-2:2006).

\section{Gęstość zaczynu cementowego}

Gęstość zaczynu cementowego odgrywa kluczową rolę w projektowaniu zabiegu cementowania. Generalnie odpowiedni dobór gęstości każdego zaczynu ma do spełnienia dwa podstawowe zadania, a mianowicie:

- zapobiegać ucieczkom płuczki lub innych płynów do formacji;

- zapobiegać dopływom płynu złożowego z warstw przepuszczalnych.
Z funkcji tych płynie wniosek, że dobór gęstości zaczynu cementowego musi wynikać z gradientów ciśnień porowych oraz z ciśnień szczelinowania i jednocześnie uwzględniać opory hydrauliczne wynikające z procesu przetłaczania zaczynu. Warto również dodać, że dobór gęstości dla danego zaczynu cementowego musi być zawsze rozpatrywany w aspekcie zjawiska budowy wytrzymałości żelowej zaczynu w czasie, jak również wytrzymałości kamienia cementowego oraz stabilności samego zaczynu. Ta ostatnia cecha wiąże się ściśle z możliwością mieszania zaczynu z różnymi dodatkami, które mogą mieć istotne znaczenie dla jego stabilności.

Kwestia budowy wytrzymałości żelowej zaczynu w czasie zależy od gęstości zaczynu. Na skutek żelowania zaczynu następuje utrata oddziaływania hydrostatycznego płynnego słupa cieczy, czyli zaczynu cementowego. Zjawisko to jest istotne w sytuacjach, gdy w zabiegu cementowania stosuje się dwa różne (pod względem gęstości) zaczyny.

Ocena utraty oddziaływania hydrostatycznego na podstawie oceny budowy struktury żelowej dla „lekkiego” cementu może okazać się kluczowa dla zachowania równowagi ciśnień w strukturze skała-kamień cementowy-rura okładzinowa. Innymi słowy: szybsza budowa struktury żelowej „lekkiego” zaczynu w stosunku do „cięższego” zaczynu może wywołać dopływ płynu złożowego i niekorzystnie wpłynąć na właściwe uszczelnienie cementowanego otworu.

\section{Czas gestnienia zaczynu cementowego}

Czas gęstnienia zaczynu cementowego dobierany jest do warunków otworowych (ciśnienie, temperatura) oraz wynika z technologicznych parametrów czasu wytłaczania zaczynu (dobicia klocka) przy założonych parametrach wydajności dla poszczególnych przetłaczanych płynów (płuczka, bufor, zaczyn cementowy i tzw. przybitka, czyli płyn wytłaczający zaczyn poza rury).

Generalnie za czas gęstnienia zaczynu uważa się czas, w którym zaczyn jest na tyle płynny, że jest „,pompowalny”, czyli może być tłoczony. Czas gęstnienia zaczynu określa się laboratoryjnie i wynika on m.in. z wartości wskaźnika Bc, a jego graniczną wartością, jaka jest dopuszczalna dla przetłaczania, jest wartość $<70$ Bc. W celu właściwego uchwycenia czasu gęstnienia zaczynu określa się również czas odpowiadający wartości 30 Bc i porównuje z wartością czasu, jaka wynika z uzyskania 70 Bc. Porównanie to daje bardziej rzetelny obraz dla ustalenia finalnego czasu gęstnienia (uwzględniając margines bezpieczeństwa), który nie powinien być zbyt długi po wytłoczeniu finalnym zaczynu, ponieważ wydłuża proces żelowania i może powodować nadmierną sedymentację fazy stałej. Jak już powyżej wspomniano, zjawiska te wpływają na utratę oddziaływania hydraulicznego wiążącego zaczynu cementowego, powodując zakłócenie równowagi ciśnień w otworze. 


\section{Filtracja zaczynu cementowego}

Zjawisko filtracji zaczynu cementowego, a w konsekwencji wielkość tej filtracji określana w centymetrach sześciennych według obowiązujących w badaniach laboratoryjnych metod, odgrywa kluczową rolę w zapobieganiu dopływu płynu złożowego w trakcie zabiegu cementowania. Wielkość filtracji oraz jej natężenie mają istotny wpływ na zachowanie równowagi ciśnień w otworze i utrzymanie minimalnego (wymaganego przepisami) nadciśnienia w stosunku do założonych ciśnień porowych. Zbyt duża filtracja zaczynu cementowego, w szczególności w strefach, gdzie można spodziewać się dopływu płynu złożowego (gaz, ropa naftowa, solanka), jest bardzo niekorzystna nie tylko z punktu widzenia zachowania równowagi ciśnień, ale może mieć też fatalny wpływ na samą jakość cementowania w ocenie profilowania RBT.

Zasadniczo nie ma zaleceń co do stosowania zaczynów cementowych o określonych wartościach filtracji, niemniej jednak jako generalną zasadę stosowaną w cementowaniu uznaje się regułę, że kontrola wielkości filtracji zaczynu jest preferowana dla stref o potencjalnym dopływie płynu złożowego. Tam, gdzie spodziewany jest dopływ płynu złożowego oraz w strefach o dużej przepuszczalności, wielkość filtracji musi być możliwie jak najmniejsza, z zachowaniem optymalnych innych cech reologicznych zaczynu, w szczególności gęstości i granicy płynięcia.

W przypadku mniej istotnych zabiegów z punktu widzenia znaczenia jakości cementowania dla uszczelnienia danej kolumny rur okładzinowych parametr wielkości filtracji zaczynu nie jest aż tak istotny i może kilkakrotnie przekraczać wartość, jaka jest wymagana dla stref o potencjalnym dopływie płynu złożowego.

\section{Stabilność zaczynu cementowego, sedymentacja, wolna woda (odstój)}

Stabilność, czyli zachowanie jednorodności zaczynu cementowego, jest istotną właściwością zaczynu dla przeciwdziałania przepływu płynów w przestrzeni pierścieniowej (rura-zaczyn lub skała-zaczyn). Zjawisko powstawania wolnej wody (odstoju) i zjawisko sedymentacji mogą pojawiać się jednocześnie lub niezależnie, tzn. powstanie wolnej wody niekoniecznie może wywołać zjawisko sedymentacji. Zjawisko powstawania wolnej wody powoduje tworzenie kanałów i przestrzeni w zaczynie i kamieniu cementowym, które są naturalnymi drogami dopływu płynu złożowego. Taka sytuacja prowadzi do zaburzenia równowagi ciśnień i wywołuje powstanie warunków podciśnienia w stosunku do ciśnień porowych, co może spowodować uruchomienie dopływu i przepływu płynów złożowych. Kontrola powstawania wolnej wody jest imperatywem w projektowaniu zaczynu, szczególnie dla stref, gdzie można spodziewać się dopływu płynów złożowych, nie mówiąc już o wpływie, jaki parametr ten wywiera na jakość cementowania, czyli wypełniania podstawowych funkcji uszczelnienia rur okładzinowych. Powstawanie wolnej wody i tworzenie się kanałów to nie tylko kwestia zaburzenia równowagi ciśnień, ale również kwestia jakości zaczynu, jaki pozostaje po uwolnieniu się wody ze struktury zaczynu. Wraz z separacją wody z zaczynu następuje zagęszczenie się cząsteczek pozostałego cementu, co ma niekorzystny wpływ na kontrolę procesu żelowania (praktycznie nie ma kontroli nad tym procesem), a tym samym zmianę innych parametrów zaczynu, w tym zdolności do transmisji ciśnienia hydrostatycznego, jakie powinno być wywierane na określone warstwy zawierające płyn złożowy, lub ciśnienia oddziałującego na daną kolumnę rur okładzinowych. Dodatkowo sedymentacja, która powoduje zagęszczenie się cząsteczek cementu w dolnej partii zaczynu i obniżenie koncentracji cząsteczek w górnej partii zaczynu, prowadzi do zmiany warunków rozkładu ciśnień działających na strefy przepuszczalne i zmiennego ciśnienia, jakie działa na rury okładzinowe. Taka zmiana w sedymentacji powoduje automatycznie zmiany w procesie żelowania zaczynu, przy czym w przypadku większej koncentracji cząstek proces żelowania jest większy i odwrotnie, co oznacza obniżenie wytrzymałości kamienia cementowego i zwiększoną przepuszczalność takiej strefy o niższej koncentracji cząsteczek cementu.

\section{Reologia zaczynu cementowego}

Reologia zaczynu cementowego ma wpływ na wytłaczanie płynów i wielkość oporów hydraulicznych w trakcie zabiegu cementowania. Parametry reologiczne zaczynu zależne są w dużym stopniu od temperatury, jaka istnieje w otworze w trakcie zatłaczania zaczynu (w mniejszym stopniu od ciśnienia wgłębnego) i zasadniczo podnosi parametry reologiczne zaczynu, a w niektórych przypadkach stabilność zaczynu cementowego jest wprost zależna od jego reologii. Dodatek niektórych komponentów do zaczynu cementowego w celu kontroli parametrów reologicznych może mieć istotny wpływ na przebieg procesu żelowania zaczynu. W projektowaniu zaczynu cementowego jego reologia jest istotna $\mathrm{z}$ punktu widzenia efektywności wytłaczania zaczynu w powiązaniu z reologią zarówno buforu, jak i płuczki wiertniczej. Zgodność reologiczna poszczególnych płynów w projekcie cementowania stanowi ważny czynnik dla właściwego wypełnienia przestrzeni pierścieniowej cementem i uzyskania dobrej jakości kamienia cementowego nie tylko pod względem parametrów mechanicznych, ale także pod względem jednorodności struktury i związania z rurą okładzinowa i ze skałą.

\section{Statyczna wytrzymałość strukturalna zaczynu cementowego - SGS}

Proces żelowania zaczynu cementowego następuje praktycznie natychmiast po zakończeniu jego wytłaczania. Budowanie 
struktury żelowej jest opisane i udokumentowane w licznej literaturze przedmiotu na podstawie wielu niezależnych badań laboratoryjnych i badań stanowiskowych (PN-EN ISO 10426-6:2012).

Tworzenie się struktury żelowej zaczynu prowadzi do powstania specyficznej cechy tworzywa określanej mianem statycznej wytrzymałości strukturalnej zaczynu, zwanej w nomenklaturze angielskiej static gel strength, w skrócie: SGS. W dalszym tekście artykułu autorzy posługują się tym skrótem jako powszechnie przyjętym i stosowanym w procedurach obowiązujących w projektowaniu i badaniach laboratoryjnych według PN-EN ISO 10426-6:2012.

Tworzenie się struktury żelowej i SGS jest jednym z istotnych czynników mających wpływ na rozkład ciśnienia hydrostatycznego w strukturze rura-zaczyn-skała.

W momencie kiedy struktura żelowa zaczynu cementowego zaczyna wchodzić w interakcję, czyli wzajemne oddziaływanie pomiędzy rurami okładzinowymi i ścianą otworu, rozpoczyna się automatycznie proces utraty zdolności transmisji ciśnienia hydrostatycznego, jak również utraty właściwości zaczynu polegającej na utrzymywaniu fazy stałej w warunkach statycznych (po zakończeniu tłoczenia zaczynu i dobiciu klocka cementacyjnego).

W literaturze przedmiotu opisuje się metody oceny wpływu tworzenia się struktury żelowej (SGS) na ewentualny dopływ płynu złożowego (gaz, solanka). Ocena ta polega m.in. na obliczeniu wartości SGS, zwanej dalej CSGS (ang. calculated static gel strength), dla danych warunków otworowych i z kolei pomiarze tej wartości w warunkach laboratoryjnych (API, 2010).

CSGS jest zdefiniowana jako wartość wytrzymałości żelowej zaczynu w aspekcie rozkładu ciśnienia hydrostatycznego do momentu osiągnięcia równowagi ciśnienia, czyli równowagi hydrostatycznej w odniesieniu do wartości ciśnienia porowego dla danej formacji złożowej, z której spodziewany jest potencjalny dopływ płynu złożowego.

Wartość danego CSGS jest obliczana na podstawie następującego wzoru (Nelson, 1990):

$$
\mathrm{CSGS}=\mathrm{OBP} \times 300+L / D_{e f f}
$$

gdzie:

OBP - początkowe nadciśnienie wywierane na złoże lub strefę stanowiącą różnicę pomiędzy ciśnieniem hydrostatycznym zaczynu a ciśnieniem porowym (wyrażone w jednostkach psi),

300 - współczynnik przeliczeniowy,

L - wysokość (długość) słupa zaczynu cementowego ponad strefę dopływu płynu złożowego (w stopach),

$D_{\text {eff }}$ - średnica efektywna (w calach), stanowi różnicę pomiędzy średnicą zewnętrzną rur okładzinowych a średnicą otworu (w calach).
Zaprezentowany wzór (1) do obliczenia CSGS w jednostkach psi może być przekształcony dla jednostek SI niemniej jednak z uwagi na fakt, że wartość CSGS najczęściej oblicza się na podstawie specjalnego programu komputerowego, stosowanie wzoru (1) jest obligatoryjne.

Finalny wynik obliczeń wyrażony w jednostkach psi może być przeliczany na jednostki SI, np. Pa lub MPa.

Jak wykazały badania laboratoryjne opisane m.in. przez Poura i Moghadasiego (2007), zaczyn cementowy, który osiągnął wartość SGS w przedziale 250-500 lbf/100 ft ${ }^{2}$ lub 125-250 Pa (co wyraża się jako wytrzymałość strukturalna), blokuje skutecznie dopływ płynu złożowego, a w przypadku dopływu gazu - jego „perkolację”, czyli bąbelkową penetrację zaczynu cementowego.

W praktyce przyjmuje się ze względów bezpieczeństwa konserwatywnie górną granicę CSGS, czyli 500 lbf/100 ft² lub $250 \mathrm{~Pa}$, co pozwala na uniknięcie pomyłek w ocenie rodzaju i jakości dopływającego medium złożowego. Regulacja wartości CSGS może wynikać jedynie z regulacji gęstości zaczynu cementowego, natomiast inne parametry reologiczne nie mają praktycznie znaczenia. Oczywiste jest, że regulacja tej wartości może być wynikiem zmiany średnicy zapuszczanych rur okładzinowych i średnicy otworu, ale tego rodzaju rozwiązania stosowane są w sytuacjach, gdy problem potencjalnego dopływu płynu złożowego (szczególnie gazu) jest bardzo dobrze rozpoznany. Przy określaniu CSGS istotny jest pomiar czasu mierzonego w pomiarach laboratoryjnych, a więc czasu od uzyskania obliczonej teoretycznej wartości CSGS do momentu osiągnięcia przez zaczyn wartości SGS na poziomie $500 \mathrm{lbf} / 100 \mathrm{ft}^{2}(250 \mathrm{~Pa})$.

Do oznaczania statycznej wytrzymałości strukturalnej SGS stosuje się np. urządzenie, w którym pomiar następuje po okresie mieszania potrzebnym do teoretycznego zatłoczenia zaczynu do przestrzeni pierścieniowej. Urządzenie zostało tak zaprojektowane, żeby symulowało warunki otworowe, które można kontrolować w czasie badania. Po symulowanym zatłoczeniu zaczynu następuje wyłączenie mieszania, a pomiar statycznej wytrzymałości strukturalnej wykonywany jest przy użyciu rotujących stale i bardzo wolno (0,5-2,0 stopni na minutę) łopatek napędzanych przez napęd magnetyczny. Metoda ta zapewnia stały i ciągły pomiar momentu obrotowego, z którego następnie, znając geometrię łopatek, oblicza się statyczną wytrzymałość strukturalną. Rysunek 3 przedstawia poglądowy schemat aparatu do pomiaru SGS.

Konfrontacja wyników obliczeń CSGS z wynikami pomiarów laboratoryjnych i ustalenie czasu żelowania do osiągnięcia wartości 500 lbf/100ft² (250 Pa) jest wskaźnikiem określającym poprawność parametrów zaprojektowanego zaczynu cementowego. Generalnie przyjmuje się, że jeżeli czas ten dla osiągnięcia CSGS wynosi 45 min i mniej, wówczas należy 


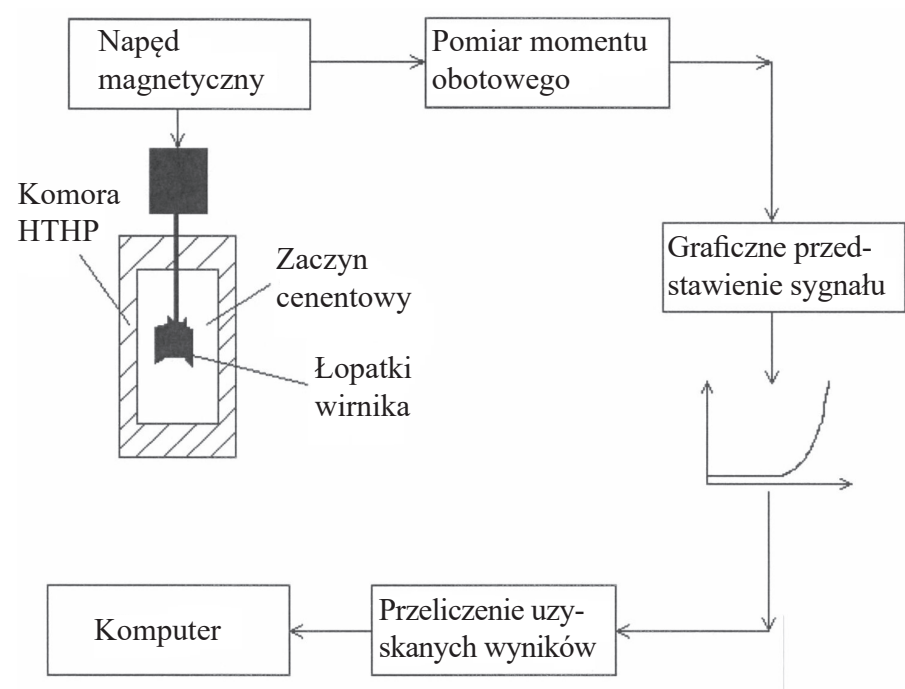

Rys. 3. Schemat aparatu Static Gel Strength Measurement

Fig. 3. Diagram of the Static Gel Strength Measurement instrument

zakładać, że proces żelowania i zabezpieczenia dopływu płynu złożowego do otworu jest pod kontrolą, co oznacza jednocześnie prawdopodobnie dobrą jakość stanu zacementowania otworu, która musi być potwierdzona profilowaniem RBT.

Zaznaczając bardzo istotną kwestię, jaką jest tworzenie się żelowej struktury zaczynu, która prowadzi do zmiany rozkładu ciśnienia hydrostatycznego, należy podkreślić, że proces ten jest funkcją kinetyki procesu hydratyzacji cementu i jest uzależniony w głównej mierze od:

- temperatury, jaka panuje w otworze w trakcie wiązania zaczynu;

- właściwości chemicznych i fizycznych samego cementu;

- dodatków chemicznych, jakie dodawane są do zaczynu, które mogą wpływać na kinetykę procesu hydratacji cementu i regulować przebieg procesu żelowania.

\section{Kontrola i badania wytrzymalości kamienia cementowego - ultrasonic cement analysis (UCA)}

Jednym $\mathrm{z}$ istotnych parametrów w ocenie stanu zacementowania rur jest jakość kamienia cementowego powstającego w procesie hydratacji zaczynu. Mechaniczne parametry związanego zaczynu cementowego-kamienia cementowego, takie jak wytrzymałość na ściskanie, wytrzymałość na rozciąganie, moduł Younga, moduł Poissona, wytrzymałość na przyczepność (kohezja), wewnętrzny kąt tarcia itd., stanowią podstawowe wskaźniki oceny jakości zabiegu cementowania rur okładzinowych. Ocena ta odbywa się już w badaniach UCA na poziomie laboratoryjnym w momencie projektowania zaczynu cementowego oraz w badaniach profilowania akustycznego RBT lub CBL w zacementowanych rurach okładzinowych po uzyskaniu minimalnej wytrzymałości kamienia na ściskanie $k_{c}$, określonej na podstawie pomiarów w aparaturze UCA (rys. 4) lub w trakcie badań wytrzymałościowych na próbkach związanego cementu.

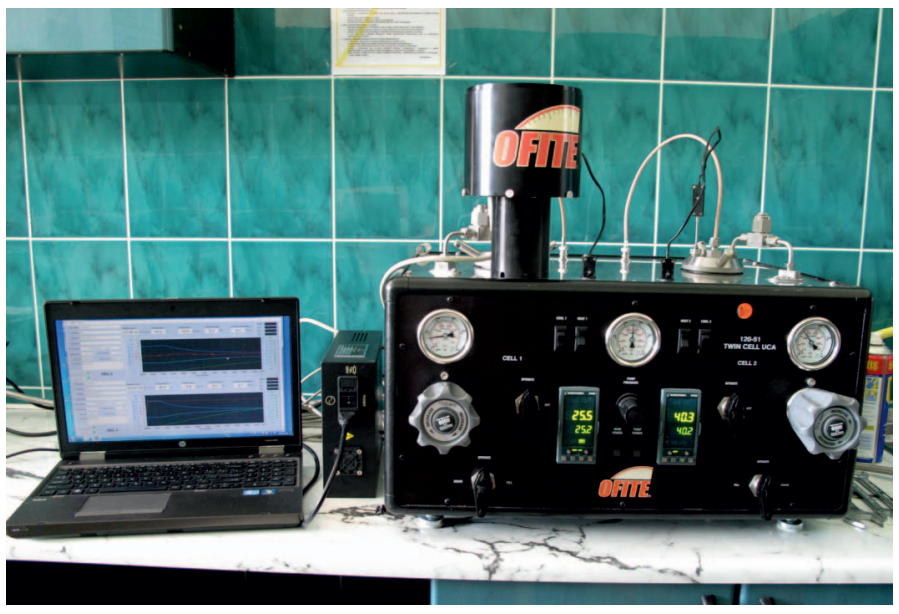

Rys. 4. Ultradźwiękowy analizator cementu (Ultrasonic Cement Analyzer) z nakładką SGSM (Static Gel Strength Measurement)

Fig. 4. Ultrasonic Cement Analyzer with the SGSM (Static Gel Strength Measurement additional accessory)

Zachowanie i ocena in situ nowej struktury po cementowaniu rura-kamień cementowy-skała jest zagadnieniem bardzo skomplikowanym i zasadniczo nie sposób ocenić rodzaju i wielkości naprężeń, jakie powstają w takiej strukturze po związaniu zaczynu, a w szczególności naprężeń w strukturze samego kamienia względem potencjalnych obciążeń tego kamienia, jakie mogą się pojawić w okresie eksploatacji odwiertu lub danej kolumny rur okładzinowych.

Naprężenia te wywierane są na strukturę kamienia poprzez:

- zmiany temperatury $\mathrm{w}$ otworze $\mathrm{w}$ procesie wiercenia lub eksploatacji;

- testy ciśnieniowe na rurach wynikające z programu wiercenia lub eksploatacji;

- zmiany równowagi ciśnień w obrębie danej kolumny rur okładzinowych, w szczególności przy opróżnieniu rur;

- zmniejszanie się ciśnień złożowych związane z eksploatacją złoża.

Wszystkie te czynniki mogą być przyczyną powstawania szczelin na styku rura okładzinowa-kamień cementowy lub kamień cementowy-skała i powodować jego destrukcję poprzez przekroczenie wytrzymałości na rozrywanie lub ściskanie albo kombinację tych naprężeń.

Badania UCA są wykonywane w całym okresie procesu żelowania i wiązania zaczynu do uzyskania określonej i wymaganej w projekcie wartości $k_{c}$ (wytrzymałości kamienia cementowego na ściskanie) lub dłużej, natomiast profilowanie CBL lub RBT wykonuje się po uzyskaniu wartości $k_{c}>7 \mathrm{MPa}$ lub po okresie wiązania zaczynu, tzw. WOC (stójki na związanie cementu), ustalonej na podstawie decyzji kierownika ruchu zakładu i na podstawie ewentualnie pomiarów UCA.

Obydwa badania, czyli UCA oraz CBL lub RBT, są pomiarami akustycznymi polegającymi generalnie na profilowaniu przebiegu fali akustycznej przez poszczególne ośrodki, czyli 
skałę-kamień cementowy-rurę okładzinową, i na ocenie charakteru tego zapisu na tle określonych wzorców. Jeżeli badanie UCA wskazuje generalnie na wynik, jaki osiąga kamień cementowy na ściskanie w czasie, to profilowanie CBL lub RBT uwzględnia wartość $k_{c}$ kamienia cementowego, rodzaj stosowanej płuczki oraz rodzaj i właściwości skały.

Z uwagi na brak informacji o rozkładzie naprężeń w strukturze kamienia cementowego, jaki powstał w obrębie przestrzeni pierścieniowej rura-ściana otworu, profilowanie CBL lub RBT to profilowanie względne i podlega jedynie interpretacji jakości związania cementu z rurą lub skałą, i jest określane jako:

- dobre lub bardzo dobre;

- słabe lub bardzo słabe;

- brak związania.

Tego rodzaju przyjęty sposób interpretacji nie daje żadnych podstaw do określenia skuteczności cementowania w zakresie np. stwierdzenia pełnej izolacji danej strefy otworu lub braku wolnej przestrzeni na styku kamienia cementowego z rurą okładzinową lub ze ścianą otworu. W praktyce bardzo rzadko występuje sytuacja interpretowana jako „,bardzo dobre związanie" - czy to ze skałą, czy to z rurą. Wynika to ze skomplikowanego procesu samego wiercenia otworu i jego cementowania. Różnorodność i zmienność warunków geologicznych, anizotropia środowiska skalnego, uwarunkowania techniczne wynikające $\mathrm{z}$ technologii wiercenia i jakość wykonania otworu, dostosowanie technologii płuczkowej do warunków otworowych i finalnie kompatybilne dostosowanie zaczynu cementowego do warunków otworowych powodują, że ocena stanu cementowania przy zastosowaniu technik CBL lub RBT musi być relatywna i sugestywna, a nie wskaźnikowa, chociaż w profilowaniu tym stosuje się tzw. bond index, który wskazywałby na zagwarantowanie trwałości związania kamienia określonego wartościami np. ciśnienia jako wskaźnika adhezji lub minimalnego wskaźnika izolacji, określonego doświadczalnie na poziomie laboratoryjnym.

W profilowaniu CBL lub RBT występuje często tzw. microannulus, czyli miniszczelina na styku rura-kamień cementowy, która powoduje zasadniczą trudność w ocenie stopnia związania kamienia cementowego. Zjawisko powstawania miroannulus jest dobrze rozpoznane i opisane w literaturze (Nelson, 1990) i wynika nie tylko z chemicznego procesu hydratyzacji cementu, ale również może wynikać z niepoprawnego zaprojektowania i wykonania zabiegu cementowania, jak też z niewłaściwych decyzji dotyczących przeprowadzenia prób ciśnieniowych na rurach po cementowaniu lub w trakcie wiercenia otworu poniżej buta rur uprzednio zacementowanej kolumny. Opis i interpretacja jakości stanu zacementowania rur są szczegółowo przedstawione w literaturze przedmiotu (Nelson, 1990).

\section{Kurczenie się lub ekspansja zaczynu cementowego i ich skutki}

W procesie hydratacji cementu, czyli podczas reakcji z wodą, powstaje nowy produkt (zaczyn cementowy), którego finalna objętość jest mniejsza niż objętość poszczególnych składników mieszaniny. Wobec braku dostępu do nowej porcji wody w procesie wiązania zaczynu następuje w określonych warunkach otworowych proces jego kurczenia. Kurczenie cementu może występować w dwóch znaczeniach, czyli jako:

- kurczenie zewnętrzne, powodujące zmianę objętości (wymiarów zewnętrznych);

- kurczenie wewnętrzne, powodujące zwiększenie porowatości matrycy struktury cementu i tym samym redukcję ciśnienia porowego.

Pierwsze kurczenie, określane jako zewnętrzne, jest często powodem utraty szczelności kamienia cementowego i powodem oddziaływania hydrostatycznego płynu (wody zarobowej, płuczki lub płynów złożowych), jaki będzie gromadził się w powstałej szczelinie wokół rur okładzinowych i kamienia cementowego.

Z kolei kurczenie wewnętrzne cementu jest istotne dla zachowania równowagi ciśnień hydrostatycznych w procesie żelowania i tworzenia się nowej struktury, która z założenia nie powinna być przepuszczalna dla płynów złożowych (głównie gazu). Proces ten został szeroko omówiony w licznej literaturze przedmiotu (Radecki i Witek, 2000; Ridi, 2010).

Jednym ze sposobów przeciwdziałania procesowi kurczenia jest stosowanie odpowiednich dodatków pęczniejących, które - co należy mocno podkreślić - mogą obniżać parametry mechaniczne kamienia cementowego i w sposób zasadniczy negatywnie wpływać na powstawanie zjawiska microannulus.

\section{Kompatybilność płynów w cementowaniu otworów}

W procesie projektowania zabiegu cementowego należy brać pod uwagę fakt (mimo stosowania środków mechanicznej izolacji w postaci klocków cementacyjnych), że poszczególne płyny na styku mogą ulegać mieszaniu. W związku z tym $\mathrm{w}$ badaniach laboratoryjnych należy zgodnie $\mathrm{z}$ określonymi procedurami (PN-EN ISO 10426-1:2010; PN-EN ISO 104262:2006) dokonać oceny zgodności, czyli kompatybilności, poszczególnych płynów. Ocena tej zgodności polega głównie na potwierdzeniu, czy powstała mieszanina na styku dwóch płynów nie wywołuje niepożądanych reakcji chemicznych, które mogłyby negatywnie wpływać na proces zatłaczania zaczynu. Na styku mieszanych płynów może dochodzić do zmiany reologii i w przypadku niezgodności chemicznej (braku kompatybilności) powstaje mieszanina o zwiększonej lepkości, co 
może powodować nieefektywne wytłoczenie płuczki w obrębie przestrzeni pierścieniowej (rura-ściana otworu) zaczynem i jednocześnie prowadzi do wzrostu oporów hydraulicznych tłoczenia. Taki scenariusz przy braku kompatybilności przetłaczanych płynów jest jednym z głównych powodów nieskutecznego wykonania zabiegu cementowania i wywołania przez to negatywnych skutków w postaci nieszczelności i niskich parametrów mechanicznych kamienia cementowego.

Innym istotnym czynnikiem w zagadnieniu zgodności (kompatybilności) doboru płynów podczas zabiegu cementowania jest stosowanie hierarchii gęstości według następującej zasady:

$$
g_{p t} \leq g_{b} \leq g_{z c}
$$

gęstość płuczki powinna być równa lub mniejsza od gęstości buforu, a tego z kolei od gęstości zaczynu cementowego.

\section{Opis zjawiska rozkładu ciśnienia hydrostatycznego w trakcie procesu hydratacji/żelowania zaczynu cementowego}

We wcześniejszej części niniejszego artykułu poruszono już zagadnienia procesu żelowania zaczynu cementowego i powstawania nowej struktury, w tym opisano znaczenie wartości CSGS i SGS, jak również innych parametrów - głównie parametrów mechanicznych tworzącego się kamienia cementowego - w aspekcie mechanizmu hydrostatycznego oddziaływania płynnego zaczynu cementowego i jego przejścia w stan stały.

Badania laboratoryjne mające na celu określenie zjawisk związanych z procesem tworzenia się kamienia cementowego, a ściślej mówiąc: pomiaru zmian ciśnienia hydrostatycznego w tym procesie, były przedmiotem wielu doświadczeń opisanych w literaturze (Nelson, 1990; API, 2008).

Pierwsze istotne dowody w tym zakresie przedstawili Levine $i$ in. (1979). Badania te polegały na pomiarze rozkładu ciśnienia hydrostatycznego zaczynu cementowego w trakcie wiązania w komorze o długości około $15 \mathrm{~m}$. W wyniku pomiarów w czasie stwierdzono, że ciśnienie hydrostatyczne słupa zaczynu zmniejszało się systematycznie, osiągając wartość gradientu wody zarobowej. Ciśnienie to na końcu praktycznie spadło do zera. Wynik tego doświadczenia przedstawiono na rysunku 5. Redukcja ciśnienia hydrostatycznego wynika wprost z kurczenia się objętości zaczynu w obrębie jego matrycy w procesie hydratacji cementu, jak również z utraty wody zarobowej, jaka została związana w tym procesie. W tym momencie mamy do czynienia z utratą oddziaływania ciśnienia porowego, jakie było wywierane przez słup płynnego, niezwiązanego zaczynu cementowego. W innej publikacji (Sabins, 1982) opisano kinematykę procesu redukcji ciśnienia hydrostatycznego zaczynu w relacji do rozwoju i tworzenia się struktury żelowej zaczynu, aż do osiągnięcia charakterystycznej wartości SGS. Redukcja ciśnienia hydrostatycznego, jak wykazano w przedmiotowych badaniach, wynika również z filtracji zaczynu, czyli utraty wody w procesie hydratacji cementu, jak też ze zmniejszenia objętości zaczynu w wyniku hydratacji, a ponadto ze ściśliwości samego zaczynu cementowego. Badania te stały się podstawą do opracowania empirycznych metod w ocenie możliwości migracji gazu w trakcie procesu żelowania zaczynu.
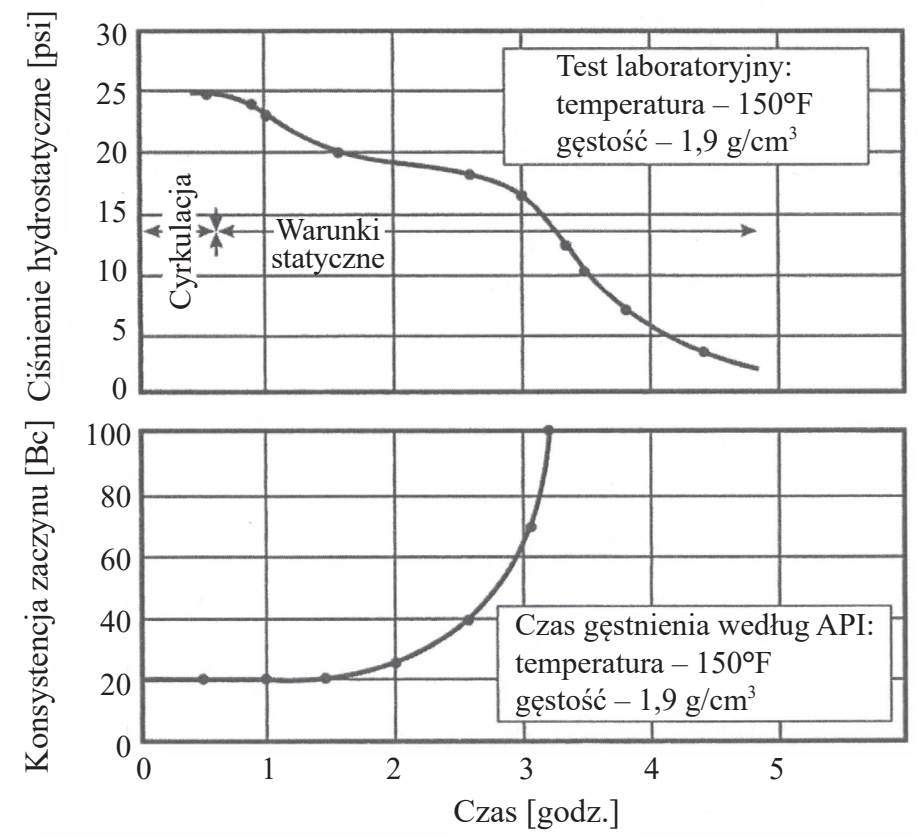

Rys. 5. Spadek ciśnienia hydrostatycznego podczas wiązania zaczynu dla cementu klasy $\mathrm{H}$ o gęstości $1,9 \mathrm{~g} / \mathrm{cm}^{3}$ na tle zmiany konsystencji wyrażonej w Bc (Levine et al., 1979)

Fig. 5. Annular gas flow test results (Levine et al., 1979) - Decay of hydrostatic pressure during gelation for H-class cement slurry, with density of $1.9 \mathrm{~g} / \mathrm{cm}^{3}$, with consistency characteristic given in $\mathrm{Bc}$

W literaturze naukowej pojawiła się również koncepcja tzw. transit time (Tinsley, 1980), czyli czasu przejściowego - okresu, w którym zaczyn nie zachowuje się już jak płyn i jednocześnie nie stanowi jeszcze związanej struktury kamienia cementowego. Interwał czasowy tego procesu oznacza, że w tym momencie następuje utrata zdolności transmisji ciśnienia hydrostatycznego przez zaczyn.

Koncepcja tego stanu przejściowego została określona jako czas od odnotowania pierwszej mierzalnej wartości żelowej zaczynu na poziomie $21 \mathrm{lb} / 100 \mathrm{ft}^{2}$ lub $10 \mathrm{~Pa}$ do stwierdzenia ustania penetracji gazu przez badany zaczyn. Penetracja gazu poprzez zaczyn cementowy stanowi najbardziej niekorzystny przypadek dla opisu zachodzącego zjawiska żelowania.

$Z$ badań tych wynika bardzo znaczący i praktyczny wniosek, który określa graniczną wartość żelowania dla penetracji gazu na poziomie 250-500 lb/100 ft ${ }^{2}$ lub 125-250 Pa.

Jako przykład przebiegu procesu żelowania i ustalania istotnych elementów tego procesu przedstawiono wykres przebiegu 
tego procesu na podstawie badania na aparacie UCA - SGSM (rys. 6). Badania wykonano dla zaczynu cementowego oznaczonego symbolem A. Skład i parametry badanego zaczynu cementowego zamieszczono w tabeli 1. Zaczyn badano w temperaturze $30^{\circ} \mathrm{C}$ i pod ciśnieniem $10 \mathrm{MPa}$. W skład zaczynu wchodziły dodatki odpieniające, upłynniające, przyspieszające, wywołujące pęcznienie oraz antyfiltracyjne. Używano również przyspieszacza wiązania. Do sporządzanego zaczynu wprowadzano lateks wiertniczy produkcji krajowej. Jako spoiwo wiążące wykorzystywano cement wiertniczy $\mathrm{G}$ z dodatkiem 10\% mikrocementu. Zaczyn cementowy A cechował się gęstością $1,82 \mathrm{~g} / \mathrm{cm}^{3}$ i nie posiadał odstoju wody. Jego filtracja wyniosła $32 \mathrm{~cm}^{3} / 30 \mathrm{~min}$. Po 3 godz. 4 minutach zaczyn uzyskał konsystencję $30 \mathrm{Bc}$, a po 3 godz. 38 minutach - $100 \mathrm{Bc}$. Koniec wiązania zaczynu nastąpił po niecałych 7 godz.

Pomiary żelowania zaczynu A wykonano na aparacie Ultrasonic Cement Analyzer - Static Gel Strength Measurement. Z rysunku 6 można odczytać, że testowany zaczyn cementowy uzyskał SGS równe $50 \mathrm{~Pa}$ po 14 minutach, a SGS równe $250 \mathrm{~Pa}$ po 36 minutach. Cechował się on zatem szybkim żelowaniem (jego transition time wynosił 22 minuty).

Badanie wczesnej wytrzymałości na ściskanie twardniejącego zaczynu cementowego o symbolu A zaprezentowano na rysunku 7. Krzywa koloru granatowego przedstawia zmiany czasu przechodzenia fali akustycznej przez badana próbkę twardniejącego zaczynu cementowego. Krzywa koloru czerwonego
Tabela 1. Skład i parametry zaczynu cementowego oznaczonego symbolem A

Table 1. Composition and parameters of cement slurry A

Sklad zaczynu cementowego o symbolu A

\begin{tabular}{|l|c|}
\hline Woda wodociągowa, w/c & $\mathrm{w} / \mathrm{c}=0,42$ \\
$\mathrm{KCl}$ (bwow) & $3,0 \%$ \\
Odpieniacz & $0,5 \%$ \\
Upłynniacz & $0,25 \%$ \\
Przyspieszacz wiązania & $0,5 \%$ \\
Dodatek antyfiltracyjny & $0,1 \%$ \\
Lateks wiertniczy & $10,0 \%$ \\
Stabilizator lateksu & $1,0 \%$ \\
Mikrocement & $10,0 \%$ \\
Cement wiertniczy G & $100 \%$ \\
Dodatek spęczniający & $0,2 \%$ \\
\hline
\end{tabular}

Odczyty reologii z aparatu Fann: R1-B1-F1

\begin{tabular}{|l|c|c|c|c|c|c|c|c|}
\hline Obroty na minutę & 600 & 300 & 200 & 100 & 60 & 30 & 6 & 3 \\
\hline Odczyt z aparatu & 138 & 75 & 51 & 29 & 18 & 12 & 4 & 3 \\
\hline
\end{tabular}

Parametry zaczynu cementowego o symbolu A

\begin{tabular}{|c|c|c|c|}
\hline Gęstość [g/cm³] & 1,82 & & \\
\hline Odstój wody [\%] & 0,0 & & \\
\hline \multirow{2}{*}{ Czas gęstnienia [h:min] } & \multirow{2}{*}{$\begin{array}{c}30^{\circ} \mathrm{C} \\
10 \mathrm{MPa}\end{array}$} & $30 \mathrm{Bc}$ & $3: 04$ \\
\hline & & $100 \mathrm{Bc}$ & $3: 38$ \\
\hline Początek wiązania [h:min] & \multirow{3}{*}{$30^{\circ} \mathrm{C}$} & \multicolumn{2}{|c|}{$5: 45$} \\
\hline Koniec wiązania [h:min] & & \multicolumn{2}{|c|}{$6: 45$} \\
\hline Filtracja $\left[\mathrm{cm}^{3} / 30 \mathrm{~min}\right]$ & & \multicolumn{2}{|c|}{32} \\
\hline
\end{tabular}
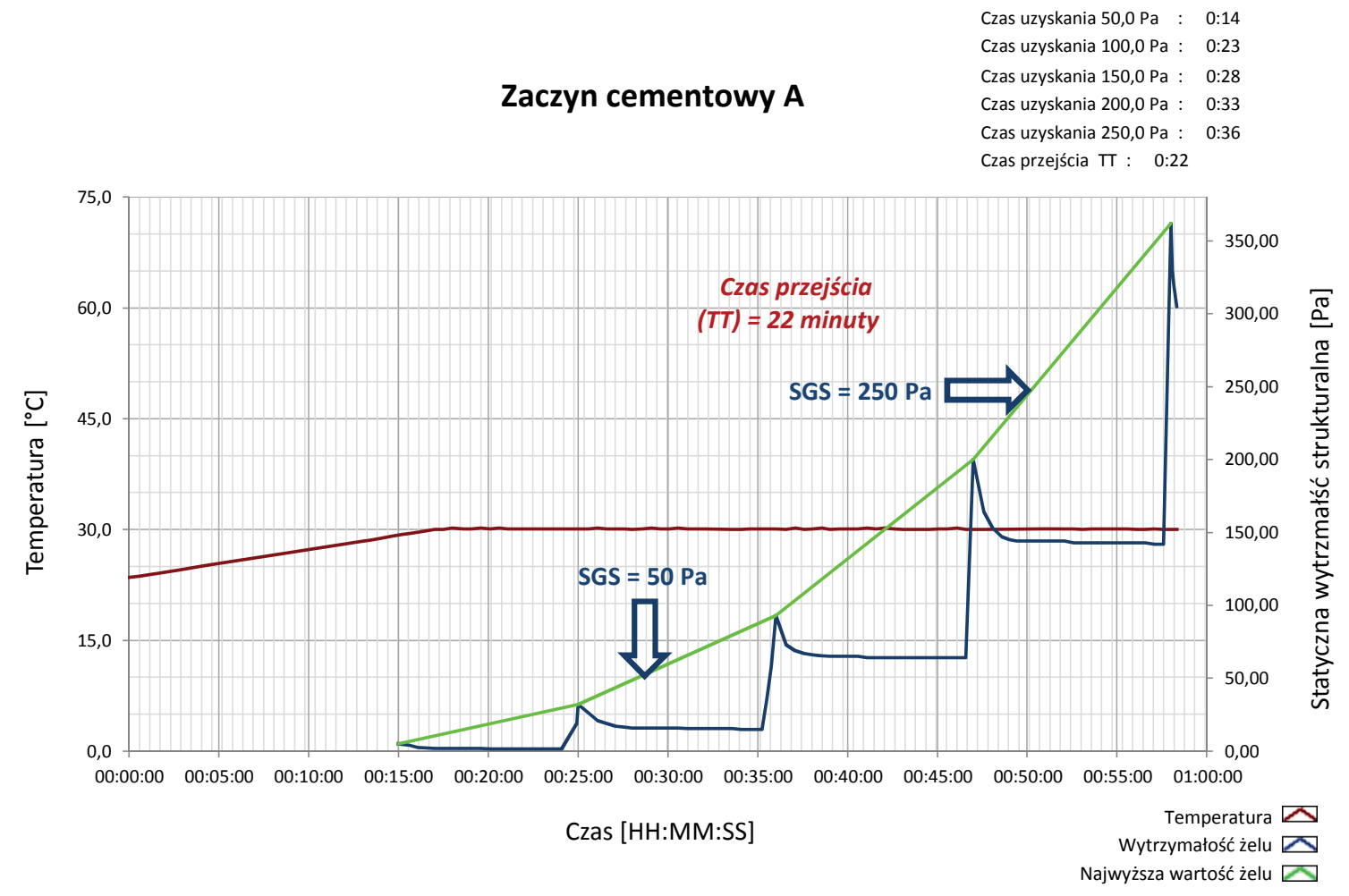

Rys. 6. Narastanie statycznej wytrzymałości strukturalnej dla zaczynu cementowego A

Fig. 6. Static gel strength development for cement slurry A 


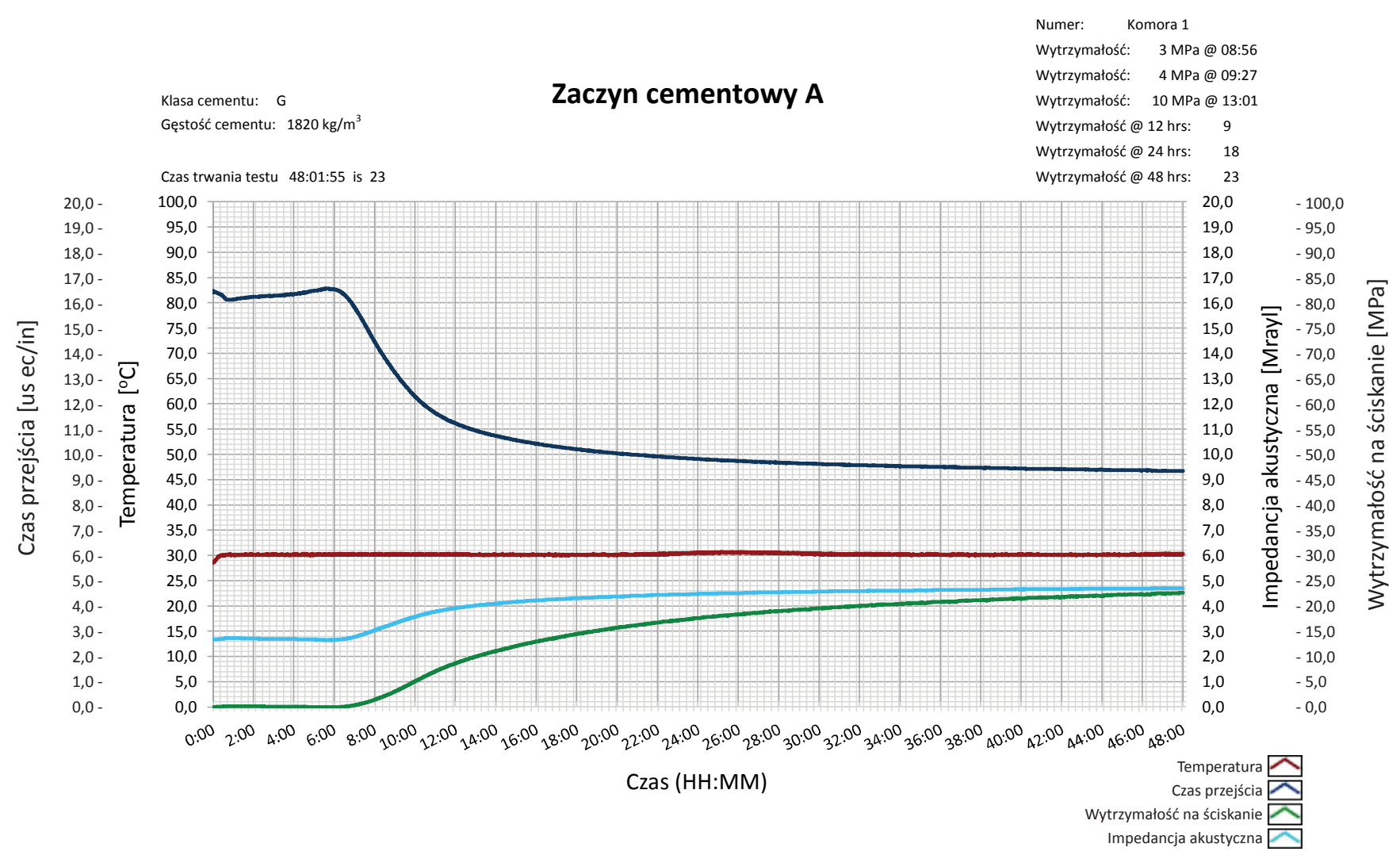

Rys. 7. Narastanie wczesnej wytrzymałości na ściskanie na UCA dla zaczynu A

Fig. 7. Development of early-age compressive strength (UCA) of sample A

obrazuje zmiany temperatury, a krzywa koloru niebieskiego - zmiany impedancji akustycznej próbki. Kolorem zielonym oznaczona jest krzywa narastania w czasie wczesnej wytrzymałości na ściskanie. Na rysunku widać, że twardniejący zaczyn osiąga początkową wytrzymałość na ściskanie wynoszącą 3,5 MPa po czasie około 9 godzin. Po 24 godzinach wytrzymałość na ściskanie próbki wzrasta do wartości $18 \mathrm{MPa}$, a po 48 godzinach - do $23 \mathrm{MPa}$.

Znaczące i istotne doświadczenia dla zrozumienia kinetyki procesu żelowania i utraty transmisji ciśnienia hydrostatycznego zostały udokumentowane przez Cooke'a i innych w przeprowadzonych badaniach (Cooke et al., 1983, 1984). Wyniki badań utraty transmisji i oddziaływania ciśnienia hydrostatycznego słupa płuczki i zaczynu cementowego zostały opublikowane w artykułach SPE nr 11206 i nr 11416, jak również w Journal of Petroleum Technology w sierpniu $1983 \mathrm{r}$. i w grudniu 1984 r. Autorzy artykułów badali i rejestrowali w czasie rozkład ciśnienia hydrostatycznego w przestrzeni pierścieniowej za pomocą czujników ciśnienia rozmieszczonych na różnych głębokościach na rurach okładzinowych. Czujniki te były połączone przewodami doprowadzonymi do powierzchni terenu, czyli głowicy otworu, i podłączonymi do specjalnych rejestratorów ciśnienia.

Pomiary wykonywano w kilku otworach przed, w trakcie, jak i po zakończeniu zabiegu cementowania. W niektórych otworach prowadzone przez kilka miesięcy pomiary potwierdziły, że proces redukcji ciśnienia hydrostatycznego wywieranego przez kolumnę pozostałej, niewytłoczonej przez zaczyn cementowy płuczki wiertniczej miał charakter długoczasowy.

Cooke i inni w cytowanych opracowaniach odkryli i udokumentowali fundamentalne mechanizmy, wyjaśniając inne podobne teorie na temat utraty oddziaływania hydrostatycznego związanego zaczynu cementowego, jednocześnie obalając przeciwstawne teorie dotyczące tego zagadnienia (Alberta Energy Regulator, 2009).

Badania udokumentowane przez Cooke'a i innych zostały niezależnie zweryfikowane i opisane w artykule SPE-19552-MS (Morgan, 1989). Autor opisuje i dokumentuje w swojej pracy wyniki badań podobnych do tych, jakie przeprowadził Cooke, mierząc za pomocą czujników ciśnienie hydrostatyczne podczas zapuszczania i cementowania rur okładzinowych na jednym z otworów na Morzu Północnym.

Na rysunku 8 pokazano jako przykład wykonanych przez Cooke'a i innych autorów pomiarów rozkład ciśnienia hydrostatycznego w przestrzeni pierścieniowej na tle rozkładu temperatury w otworze A.

$Z$ wykresów zamieszczonych na rysunku 8 wynika jednoznacznie, że w momencie zakończenia wytłaczania zaczynu cementowego czujniki ciśnienia rozmieszczone na różnych głębokościach w kolumnie rur okładzinowych rejestrują 


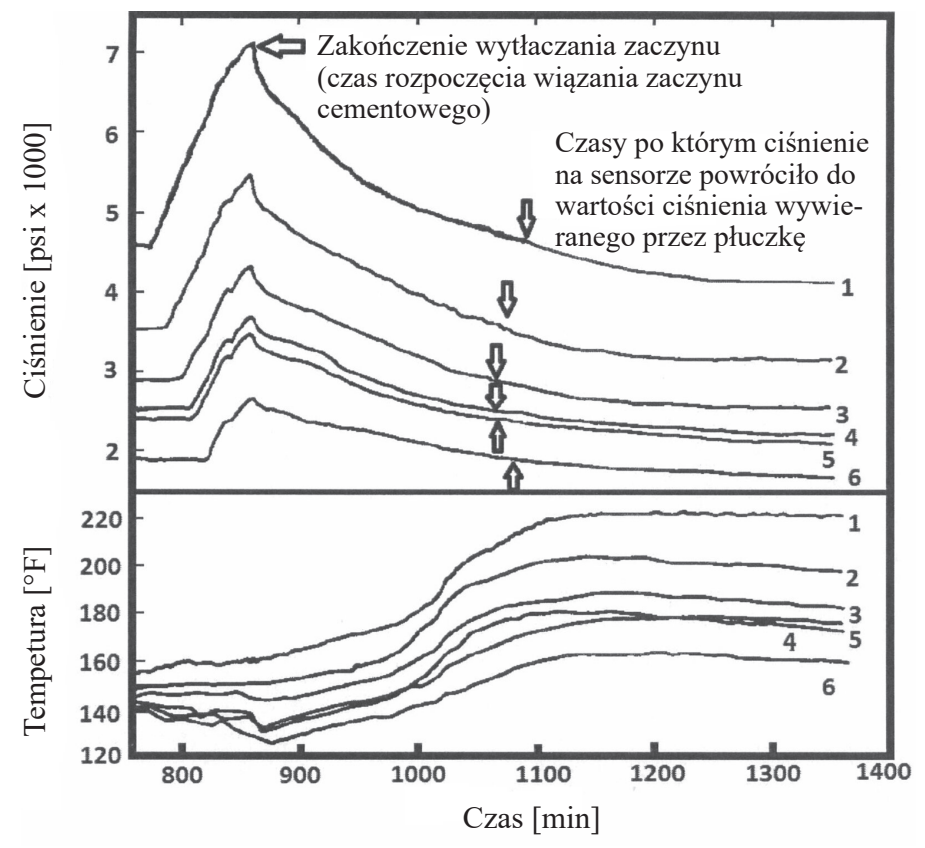

Rys. 8. Rozkład ciśnienia hydrostatycznego i temperatury w trakcie wiązania zaczynu cementowego mierzony na różnych głębokościach w przestrzeni pierścieniowej przykładowego otworu (Cooke et al., 1983). Numery czujników i ich głębokości wyrażone w stopach: 1 - 8754, 2 - 6909, 3 - 5488, 4 - 4787, 5 - 4632, 6 - 3636

Fig. 8. Annular pressure and temperature decay for well A (according to Cooke et al., 1983). Measurements during gelation of slurry in annulus at different depths

systematyczny spadek ciśnienia do poziomu gradientów wody zarobowej (solanki, wody morskiej lub płuczki). Efekt takiego oddziaływania zredukowanego ciśnienia hydrostatycznego w procesie wiązania zaczynu cementowego jest istotny dla przyjętych procedur projektowania poszczególnych kolumn rur okładzinowych i wyznaczania określonych współczynników projektowania, tzw. współczynników bezpieczeństwa, jak również wyznaczenia granicznych obciążeń działających na daną kolumnę rur okładzinowych dla poszczególnych scenariuszy, jakie wynikają z procesu wiercenia i eksploatacji odwiertu.

\section{Podsumowanie}

W niniejszym artykule opisano zjawisko chemicznej hydratacji cementu. Ponadto omówiono poszczególne parametry zaczynu cementowego, które powinny być szczegółowo testowane podczas badań laboratoryjnych każdej receptury cementowej (m.in.: gęstość, czas gęstnienia, filtracja, stabilność sedymentacyjna zaczynu cementowego, wolna woda, parametry reologiczne). Szczególną uwagę poświęcono pomiarom statycznej wytrzymałości strukturalnej zaczynu cementowego, tzw. SGS, oraz wytrzymałości mechanicznej kamienia cementowego (badania na Ultrasonic Cement Analyzer). Autorzy zamieścili także przykładową recepturę zaczynu, dla której wykonano szczegółowe pomiary parametrów technologicznych. Ponadto opisano zjawiska rozkładu ciśnienia hydrostatycznego w trakcie procesu hydratacji i żelowania zaczynu cementowego, a także przykłady zmian ciśnienia hydrostatycznego i temperatury w trakcie wiązania zaczynu cementowego mierzonych na różnych głębokościach w przestrzeni pierścieniowej przykładowego otworu wiertniczego. Problematyka opisanych w niniejszym artykule zjawisk zostanie szeroko rozwinięta i wykorzystana w kolejnym artykule przy omawianiu zagadnień związanych z projektowaniem kolumn rur okładzinowych.

Artykuł powstał na podstawie pracy statutowej pt. Zaczyny cementowe o krótkich czasach żelowania $i$ wiazania do uszczelniania plytkich otworów wiertniczych - praca INiG - PIB na zlecenie MNiSW; nr zlecenia: 0017/KW/2018, nr archiwalny: DK-410017/2018, jak również doświadczeń i prac prowadzonych w ostatnich latach przez Firmę Konsultingową „WES”.

\section{Literatura}

Alberta Energy Regulator, 2009. Directive 010: Minimum Casing Design Requirements Dec 22, 2009. Energy Resources Conservation Board, Calgary, Canada. <https://www.aer.ca/ regulating-development/rules-and-directives/directives/directive-010> (dostęp: 09.10.2020).

API, 2008. Cement Sheath Evaluation - API Technical Report 10 TR1 Second Edition, September 2008. < https://global.ihs.com/doc detail.cfm?document_name=API\%20TR\%2010TR1\&item_s_ key $=00237621>($ dostęp: 09.10.2020).

API, 2010. Isolating Potential Flow Zones During Well Construction - API STANDARD 65 - Part 2. December 2010. <https://www. api.org/ /media/Files/Policy/Exploration/Stnd_65_2_e2.pdf $>$ (dostęp: 09.10.2020).

Cooke C.E., Kluck M.P., Medrano R., 1983. Field Measurements of Annular Pressure and Temperature During Primary Cementing. J. Pet. Technol., 35(8): 1429-1438. DOI: 10.2118/11206-PA.

Cooke C.E., Kluck M.P., Medrano R., 1984. Annular Pressure and Temperature Measurements Diagnose Cementing Operations. J. Pet. Technol., 36(12): 2181-2186. DOI: 10.2118/11416-PA.

Dębińska E., 2013. Wyznaczanie statycznej wytrzymałości strukturalnej i wczesnej wytrzymałości mechanicznej zaczynów cementowych. Nafta-Gaz, 2: 134-142.

Kurdowski W., 2010. Chemia cementu i betonu. Wydawnictwo Polski Cement $i$ Wydawnictwo Naukowe PWN, Warszawa.

Kurdowski W., 2014. Cement and concrete chemistry. Springer Science \& Business, New York.

Levine D.C., Thomas E.W., Bezner H.P., Talle G.C., 1979. Annular Gas Flow After Cementing: A Look at Practical Solutions. Society of Petroleum Engineers. DOI: 10.2118/8255-MS.

Morgan D.R., 1989. Field Measurement of Strain and Temperature While Running and Cementing Casing. SPE Annual Technical Conference and Exhibition, San Antonio, Texas. DOI: 10.2118/ SPE-19552-MS.

Nelson E.B. (ed.), 1990. Well Cementing. Schlumberger Educational Service, Houston, Texas, USA.

Neville A.M., 2000. Właściwości betonu. Wydawnictwo Polski Cement Sp. z.o.o., Kraków.

Pour M.M., Moghadasi J., 2007. New Cement Formulation that Solves Gas Migration Problems in Iranian South Pars Field Condition. 
DOI: 10.2118/105663-MS. <https://www.researchgate.net/publication/241787657_New_Cement_Formulation_that_Solves_Gas Migration_Problems_in_Iranian_South_Pars_Field_Condition> (dostęp: 09.10.2020).

Radecki S., Witek W., 2000. Dobór technik i technologii cementowania w aspekcie występowania migracji gazu. Nafta-Gaz, 9: 487-497.

Ridi F., 2010. Hydration of cement: Still a lot to be understood. Dipartimento di Chimica \& CSGI Università di Firenze, La Chimica L'Industria. <https://www.semanticscholar.org/paper/ HYDRATION-OF-CEMENT\%3A-STILL-A-LOT-TO-BEUNDERSTOOD-Ridi/057c087d7949ab2a8b6259a973db2363 72efefa7> (dostęp: 09.10.2020).

Rzepka M., Kremieniewski M., Kędzierski M., 2019. Cement slurries for sealing casing in boreholes with increased risk of gas migration. Nafta-Gaz, 9: 562-570. DOI: 10.18668/NG.2019.09.05.

Sabins F.L., 1982. Transition Time of Cement Slurries Between the Fluid and Set States. SPE J., 22(6): 875-882. DOI: 10.2118/9285-PA.

Tinsley J.M., 1980. Study of Factors Causing Annular Gas Flow Following Primary Cementing. J. Pet. Technol., 32(8): 1427-1437. DOI: 10.2118/8257-PA.

\section{Akty prawne i dokumenty normatywne}

PN-EN ISO 10426-1:2010 Przemysł naftowy i gazowniczy - Cementy i materiały do cementowania otworów. Część 1: Specyfikacja. PN-EN ISO 10426-2:2006 Przemysł naftowy i gazowniczy - Cementy i materiały do cementowania otworów. Część 2: Badania cementów wiertniczych.

PN-EN ISO 10426-6:2012 Przemysł naftowy i gazowniczy - Cementy i materiały do cementowania otworów. Część 6: Metody określania statycznej wytrzymałości strukturalnej zaczynów cementowych.
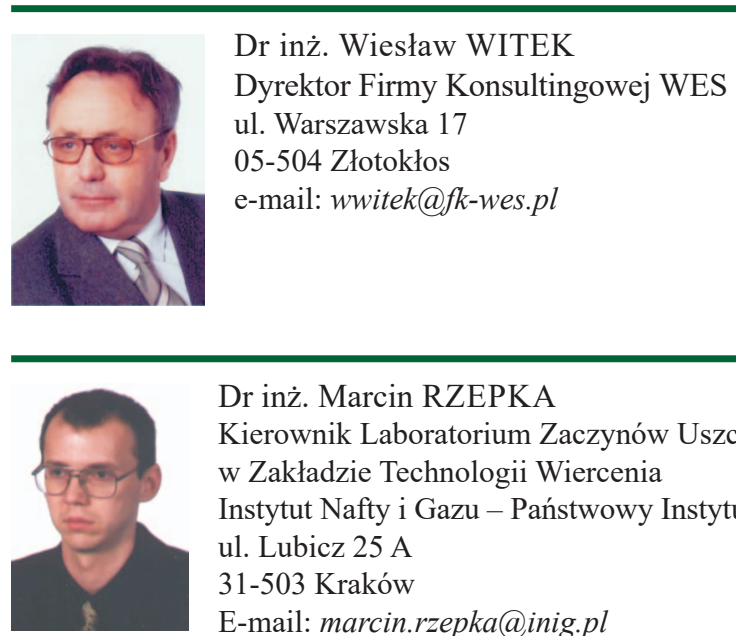

Dr inż. Marcin RZEPKA

Kierownik Laboratorium Zaczynów Uszczelniających w Zakładzie Technologii Wiercenia Instytut Nafty i Gazu - Państwowy Instytut Badawczy ul. Lubicz $25 \mathrm{~A}$

31-503 Kraków

E-mail: marcin.rzepka@inig.pl

\section{OFERTA BADAWCZA ZAKŁADU TECHNOLOGII EKSPLOATACJI PŁYNÓW ZłOŻOWYCH}

\section{Zaktad oferuje:}

- opracowanie kompleksowej technologii bioremediacji in-situ gruntu zanieczyszczonego substancjami ropopochodnymi;

- rekultywację terenów skażonych substancjami ropopochodnymi;

- opracowanie technologii oczyszczania i utylizacji wód ztożowych i odpadów po zabiegach stymulacyjnych z zastosowaniem nowoczesnych rozwiązań technicznych i technologicznych oraz metod biologicznych;

- optymalizacja procesów wydobycia i przygotowania do transportu ropy i gazu;

- monitorowanie zmian zawartości związków siarki w podziemnych magazynach gazu;

- badania i dobór inhibitorów parafinowo-hydratowych oraz deemulgatorów stosowanych w procesach eksploatacji ztóż węglowodorów.
Badania i analizy laboratoryjne:

analizy chromatograficzne:

» składu gazu ziemnego $\left(\mathrm{C}_{1}-\mathrm{C}_{8}, \mathrm{~N}_{2}, \mathrm{CO}_{2}, \mathrm{He}, \mathrm{H}_{2}\right)$,

" związków siarki w gazie ziemnym,

» węglowodorów ciężkich $\left(C_{3}-C_{36}\right.$, BTEX),

analizy toksykologiczne z wykorzystaniem nowoczesnych testów: Microtox, zestawów testów typu „toxkit” i testu MARA;

analizy zawartości wielopierścieniowych weglowodorów aromatycznych (WWA) w próbkach środowiskowych z wykorzystaniem HPLC;

analiza ptynów ztożowych, zanieczyszczeń gleby i ścieków, odpadów eksploatacyjnych i wiertniczych z wykorzystaniem chromatografii jonowe;;

- nieniszczące badania grubości materiatów konstrukcyjnych (certyfikat UT2).

Kierownik: dr hab. inż. Teresa Steliga, prof. INiG - PIB Adres: ul. Armii Krajowej 3, 38-400 Krosno Telefon: 1343660 29, 134368941 w. 5222 Faks: 134367971 E-mail: teresa.steliga@inig.pl

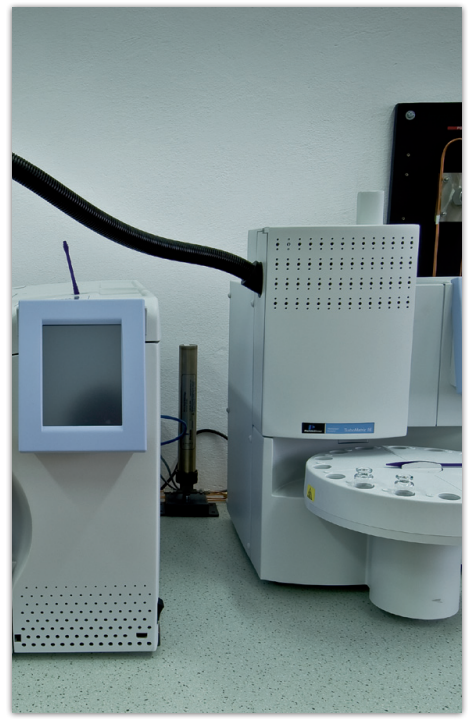

INSTYTUT NAFTY I GAZU - Państwowy Instytut Badawczy 